\title{
ANALYTIC PHILOSOPHY, PSYCHO-ANALYTIC THEORY AND FORMALISM
}

The present article treats a number of interweaving themes : the relation between philosophy and psycho-analytic theory ; Wittgenstein's critique of Freud; post-Wittgensteinian philosophy of language in the English-speaking world, and its relation to the work of Frege ; and the parallel between this Anglophone philosophy of language on the one hand, and certain tendencies in French thought on the other.

Many philosophers in Britain and America are interested in psychoanalysis. Indeed, if one may count Ludwig Wittgenstein as a philosopher of the Anglophone World ', we might even say that the debate around questions of Freudian doctrine has taken a significant place in philosophical work there.

Like Freud, Wittgenstein was a Viennese. He was, more or less inevitably, acquainted with Freud's writings ; and his sister Margarete was Freud's patient and his personal friend. Wittgenstein wrote little about Freud, but often spoke of his work in lectures or in conversations with friends and students.

In the Lectures and Conversations on Aesthetics, Psychology and Religious Belief he remarks on « something which Freud does and which seems to me immensely wrong $"$. The problem concerns the nature of psycho-analytic explanations. Freud, says Wittgenstein, suggests that behaviour can sometimes be explained by discovering, beneath the

1. Born and brought up in Austria, he worked almost exclusively in England. But cf. Allan JANIK, Stephen TouLMIN, Wittgenstein's Vienna, New York, Simon \& Schuster, 1973.

Revue de synthèse : IVe S. $\mathrm{N}^{\circ} 2$, avril-juin 1987. 
conscious motive, the true and unconscious motive. But what is the criterion for determining that the second rather than the first motive is the efficient one ? It looks as if Freud had made a discovery and at the same time introduced a method for applying it to individual cases. Wittgenstein however thinks that there is no discovery. There is rather a process of persuasion - by the analyst of the patient - which often works : the latter is persuaded that he in fact acted from a motive different from that which he previously believed to have lain behind his action. In this sense psycho-analysis offers the patient a new and different view of the world, no more or less true than his previous view, but of potential moral or therapeutic value. This argument is typical of a certain line of criticism directed against Freud's " scientific " interpretation of the status of his own work. But it is still based on a fairly superficial knowledge of the Freudian texts. Wittgenstein seems to believe, judging from these comments of 1938, that Freud's theory is a pansexualism, and even that he held that anxiety is always to be explained as a repetition of the birth trauma - which was rather a « heretical " notion of Otto Rank.

Wittgenstein appears to have been fascinated by the whole question of the " meaning " of dreams, and by Freud's work in this field. Dream images, he notes, seem to have « a certain resemblance to the signs of a language ". But if they really are symbols, as Freud claims, and can be translated into the language of ordinary speech, " then the translation ought to be possible both ways ", that is, in both directions. Yet, as Freud himself recognizes, no-one - and in particular the analyst - is able to translate " ordinary thoughts " into "dream language ". All he can do, at most, is to translate dreams, post facto, into ordinary language. So there cannot really be a language of dreams.

But the critique goes further. Freud is always looking, not just for a translation or interpretation, whether of a dream or of a remark or of a symptom, but for the "right interpretation ". Why does he believe that there is one such correct interpretation ? To this question he might respond with a counter-question : " Are you asking me to believe that there is anything which happens without a cause ? " And to identify this cause must be to give the right answer to the relevant " why " question. But this, objects Wittgenstein, would be an irrelevant response. For we ought not to be looking for a cause at all, " in the sense of some past event " connected in the appropriate way with the dream, remark or symptom. Psycho-analytical techniques (like free association) enable us to discover certain things about ourselves, but do not « explain why the dream [etc.] occurred $»$. 
It appears that Wittgenstein re-read The Interpretation of Dreams in 1946, and came to a number of conclusions in respect to Freud's doctrine : in particular that Freud had in fact - without admitting or perhaps even without being aware of this fact - propounded « a new myth ". This was the true status of psycho-analysis. To draw this conclusion was not to condemn Freudian theory, for myths have useful social functions. But it did again amount to denying it scientific status. It was around this question : Is psycho-analysis a science, and if so, in what sense ? that debate in Anglo-Saxon philosophical circles in this domain was to turn for many years, and indeed to a considerable extent still does.

In 1948 Wittgenstein returned to the question of the interpretation of dreams. What is intriguing about a dream, he says, " is not its causal connexion with events in my life, etc., but rather the impression it gives of being a fragment of a story... the rest of which remains obscure $»$. And this dream story " has a charm of its own " ${ }^{2}$. And in the Philosophical Investigations ${ }^{3}$ he again turns his attention to the applicability, in certain kinds of explanation of behaviour, of the concept of cause - but now his comments are rather more favourable to Freud's method.

Suppose, he says, that I go for a walk out of town, and after having strolled for a certain time imagine that the town now lies somewhere on my right.

"I had no reason to think it. But though I [in retrospect] see no reason, still I seem to see certain psychological causes for it. In particular, certain associations and memories... - I might try, as it were, psycho-analytically to discover the cause of my unfounded conviction. "

Yet earlier, in his Cambridge Lectures of 1932-1935, Wittgenstein claimed to have identified in Freud « a muddle... between a cause and a reason. Being clear about why you laugh is not being clear about a cause... Of course we can give causes for our laughter "; but these will be discovered experimentally, whereas the psycho-analytic way of finding out why a person laughs involves not experimentation but a procedure whereby that person (in the end) comes to agree that so-andso was indeed the reason why he laughed. And this kind of procedure is not science ; it is simply a (new) " means of representing " matters.

2. In Culture and Value, Oxford, Blackwell, 1980, p. 68-69.

3. Oxford, Blackwell, 1953, p. 215. 
G. E. Moore also reports Wittgenstein as having defended this distinction between cause and reason, in the context of a discussion of Freud's theory of the Witz.

In his Blue Book of 1933-1934 Wittgenstein characterizes Freud's use of the notion of "unconscious ideas " as primarily a terminological innovation. One should not, he says, be led astray by images and analogies suggested by this new terminology. Suppose by comparison that someone were to introduce the phrase " unconscious toothache " - a phrase which could well have a use. Our reaction might be to deny the very possibility of such a thing ; or we might be overwhelmed by the prodigious nature of the discovery. In fact it is simply a matter of choosing the more useful or convenient mode of description. A psychoanalyst would, in a similar way, be quite wrong if he supposed that he had " discovered conscious thoughts which were [actually] unconscious", or something of this confused kind.

On the one hand, Wittgenstein thus seems to have been sceptical as to the scientific claims of psycho-analysis. And on the other hand he considered it dangerous in clinical practice. He told his student Norman Malcolm in 1945 that it had done enormous harm and very little good. And yet he called himself a " disciple " of Freud !

He offered in fact three explanations of the popularity of Freudian theory. The first is that there exists in human beings a fascination with the " uncanny " 4 , which is satisfied by psycho-analysis. The second is that people have an iconoclastic tendency, which is flattered by a theory and practice that dare to talk about sexual taboos. The third claims that the attraction of psycho-analysis lies in part, and paradoxically, in its " repellent " character - an explanation-type which, as has been pointed out, can already be found in Plato. In The Republic (IV, 439-440) the latter mentions a story concerning Leontion, son of Aglaion, who had stumbled across some human corpses :

" He wanted to go back and look at them, and yet at the same time held himself back in disgust. A last his desire got the better of him and he ran up to the corpses and opened his eyes."

Plato and Wittgenstein indeed both seem to acknowledge the existence of a phenomenon which some English-language philosophers appear to

4. See Lectures and Conversations, Oxford, Blackwell, 1966, p. 25 ; cf. FreuD's article " Das Unheimliche " (1919), translated as " The "Uncanny" ", in Standard Edition, London, Hogarth, 1974, vol. XVII. 
prefer to deny. Mary Midgley, for instance, in her book Wickedness, argues to the effect that it is not plausible to suppose that death could exist as an object of desire, and - more generally - that only healthy motives are intelligible 5 .

Anthony Kenny notes ${ }^{6}$ that there is, beyond Wittgenstein's own attraction to psycho-analysis, a resemblance between psycho-analytic method and Wittgenstein's own philosophical practice. Philosophy, he believed, is useful only in application to people who are in some way sick - that is, who have (bad) philosophy inside them. But this is true of all of us! Philosophy might thus be called "therapeutic " Wittgenstein himself compared it to medicine.

Morris Lazerowitz attempted to develop this idea in a number of works, especially The Structure of Metaphysics (1955), Studies in Metaphilosophy (1964), Philosophy and Illusion (1968), and The Language of Philosophy : Freud and Wittgenstein (1977). Philosophy, claims Lazerowitz, is like a sanctuary where what normally sounds like aberrant talk is accepted as reasoned discourse. This notion is indeed contained in Wittgenstein. In On Certainty (section 467) he tells the story of a philosopher, sitting in a garden, who pointing at a tree says : "I know that that is a tree. " $\mathrm{A}$ passer-by hears him " and I tell [the passer-by] : "This fellow is not insane. We are only doing philosophy." " Bad philosophy, he observes elsewhere, is contained in the form of a mythology in our everyday language ${ }^{7}$. But this certainly does not mean that the task of philosophy is to create a new, ideal language!

Here we reach a point of some importance. Wittgenstein's interest in psycho-analysis is in part inspired, as I already noted, by the aim of " curing " people of bad philosophy. And another great example of bad philosophy is the quest for just such an ideal language. It is an old project. Among modern philosophers, its first great proponent is Leibniz. It has been given a new lease on life in recent years by the invention of logical calculi which, it is hoped, will finally allow us to eliminate the " logical defects » inherent in natural language. But it is a project which Wittgenstein rejects in several places ${ }^{8}$.

5. Wickedness : A Philosophical Essay, London, Routledge, 1984.

6. "Wittgenstein on the Nature of Philosophy ", in Brian McGuinness, ed., Wittgenstein and his Times, Oxford, Blackwell, 1982.

7. In Manuscript 213, p. 115. (For information on Wittgenstein's manuscripts and their numbering, see Georg H. vON WRIGHT, "The Wittgenstein Papers", in Wittgenstein, Oxford, Blackwell, 1982.)

8. See for example Blue and Brown Books, Oxford, Blackwell, 1958, p. 28 ; Philosophical Investigations, section 132. 
Does Freud mean to warn us against the same temptation in his New Introductory Lectures? There he writes that

" philosophy is not opposed to science, it behaves like a science and works in part by the same methods ; it departs from it, however, by clinging to the illusion of being able to present a picture of the universe which is without gaps and is coherent... It goes astray by over-estimating the epistemological value of our logical operations... $\gg 9$.

It is difficult to know exactly what Freud intended by these words. But they are perhaps congruent with Wittgenstein's standpoint. This includes a resolute opposition both to what is sometimes called the " calculus view » of language, and to the repercussions of this view inside philosophy and other intellectual enterprises. Now this standpoint has important consequences for a whole range of theoretical questions, including that of the nature of explanation in psycho-analysis.

At section 21 of the Philosophical Investigations Wittgenstein remarks that we cannot say that (natural) language approximates to a calculus. We might of course at any time extend our use of the term " language " in order to cover so-called ideal languages. But this would indeed be no more than an extension, not the core use. "Here the word "ideal" is liable to mislead ", he writes ; " for it sounds as if these languages were better, more perfect, than our everyday language $»$. This is wrong, just as it is wrong to suppose that « if anyone utters a sentence and means or understands it, he is operating a calculus according to definite rules ".

But Wittgenstein's position has been implicitly or explicitly rejected by many contemporary Anglophone philosophers. A well-known instance is the American Donald Davidson ${ }^{10}$, who believes for example that the goal of the theory of meaning - nowadays taken to be the central field of philosophy - is « to elicit in a perspicuous and general form the understanding of logical grammar [which] we all have that constitutes (part of) our grasp of our native tongue ". And this logical grammar, specified by the theory of meaning, provides us with a pertinent array of axioms and theorems, together with principles such that - according to Davidson - if someone knew them, he would be able to speak the language in question. "I dream ", he writes in a well-known phrase,

9. Lecture XXXv, in Standard Edition, op. cit. supra n. 4, 1964, vol. XXII.

10. See for example his article « The Logical Form of Action Sentences », in Nicholas ReSCHER, ed., The Logic of Decision and Action, Pittsburgh, Pittsburgh U.P., 1967 ; also "Truth and Meaning ", Synthese, 17, 1967 ; and Essays on Actions and Events, Oxford, Oxford U.P., 1980 ; Inquiries into Truth and Interpretation, Oxford, Oxford U.P., 1983. 
" of a theory that makes the transition from the ordinary idiom to canonical notation purely mechanical... " Similarly, the British philosopher Michael Dummett claims :

« It is rather generally supposed that we shall arrive at a satisfactory syntactic analysis of natural language only by exhibiting its sentences as having an underlying (or deep) structure analogous to that of sentences of Frege's formalized language $" 11$.

Such research ought, it is supposed, to help elucidate the logical grammar of what Davidson calls « mental events ». He does not himself believe that any such project is anywhere near completion ; but he does offer formal analyses of certain concepts central to the philosophy of mind. In so doing, he even proposes a " defence " of certain of Freud's ideas - but a defence of a very special kind, involving a reading of Freud quite different from that of Wittgenstein ${ }^{12}$.

The general structure of Davidson's approach lies in its attempted reconciliation of what Wittgenstein had wanted to keep apart : explanation by reference to causal connexion on the one hand and explanation by reference to intention or motive on the other. To this end it makes use of a theory, called the " theory of truth-functional semantics ", of which the original version was introduced by Alfred Tarski ${ }^{13}$. We must therefore say a few words about this theory.

In opposition to the Wittgenstein of the Tractatus Logico-philosophicus, Tarski attempted to define a " material adequacy condition " of truth by introducing a metalanguage in which it can be stipulated that :

$S$ is true if and only if $p$

whenever $" p$ " is replaced in this schema by any sentence of the language for which truth is to be defined, and « $S$ » by a name of the sentence which replaces « $p$ ». Thus, in the famous example :

"Snow is white " is true if and only if snow is white.

Tarski next specifies the syntactic structure of the object-language (L) for which truth is to be defined, and of the metalanguage (M) in which

11. See Donald Davidson, "The Logical Form of Action Sentences ", in N. RESChER, ed., op. cit. supra n. 10, p. 115 ; quoted in Gordon BAKER, Peter HACKER, Language, Sense and Nonsense, Oxford, Blackwell, 1984, p. 5 ; Michael DUMMETT, Truth and Other Enigmas, London, Duckworth, 1978, p. 118.

12. See "Paradoxes of Irrationality ", in Richard WollheIM, James Hopkins, eds, Philosophical Essays on Freud, Cambridge, Cambridge U.P., 1982, p. 289-305.

13. Alfred TARSKI, « The Semantic Conception of Truth ", in Herbert FeiGl, Wilfred SELlars, eds, Readings in Philosophical Analysis, New York, Appleton-Century-Crofts, 1949. Tarski's conception of truth is, in his own view, applicable only to formalized and not to natural languages. It was Davidson who extended it in the latter direction. 
truth-in- $\mathrm{L}$ is to be defined. He further defines the notion of « satisfaction " : so-called " open sentences " (for example : $x$ is an obsessional neurotic) are satisfied by objects (like the Rat Man and the Wolf Man). Or more exactly, the existentially quantified sentence $(\mathrm{B} x)$ ( $\mathrm{x}$ is an obsessional neurotic) is satisfied by any and every " sequence of objects " which differs from another sequence at most in the first place, simply on condition that there exists some obsessional neurotic - and therefore a sequence (the Rat Man, ...). An open sentence of the simple type already cited is then called " true " if the correlative existentially quantified sentence is satisfied in this sense.

Davidson, inspired by Tarski, now applies this doctrine to the language of mental events. He calls a sentence of the form " event $\mathrm{x}$ is $\mathrm{M}$ » a mental open sentence if and only if the expression that replaces « $M$ » contains (and essentially so) at least one mental verb. So an event is mental if and only if there is a mental open sentence true of that event (alone). Physical events, in contrast, are those picked out by open sentences containing (essentially) only the physical vocabulary.

Now we are to compare the relation between the physical and the mental vocabulary with the relation between a larguage $\mathrm{L}$ and the predicate " true-in-L ", says Davidson. We know that, in the latter connexion, there is no predicate (of syntax) of $\mathrm{L}$ which applies to all and only the true sentences of $L$. In other words, we cannot correlate - in some law-like manner - the extension of the predicate « true-in- $\mathrm{L}$ » with the extension of any predicate of $\mathrm{L}$ itself. In an analogous way, so the argument goes, we are unable to correlate the extension of any mental predicate with the extension of any predicate of the physical language. This only means that no psycho-physical laws can be formulated, for reasons of principle. For the events which instantiate laws must, in the case of any given law, all be formulated in some one vocabulary. What it does not exclude is the possibility that all mental events are (also) physical, or even that an individual mental event is caused by an individual physical event or set of events ${ }^{14}$.

On the basis of such considerations, Davidson insists that Freud can be defended on one central point, namely that there is no inherent conflict between reason explanations and causal explanations ${ }^{15}$. For beliefs and desires (the specification of whose conjunction provides reason explanations) can also be treated as causes of the actions for which they are reasons. In certain cases, including many discussed by Freud, a person

14. D. Davidson, "Mental Events ", in Ted Honderich, Myles Burnyeat, eds, Philosophy As It Is, London, Allen Lane, 1979.

15. D. DAvidson, art. cit. supra n. 12. 
will have a " reason for " acting in a certain way (e.g. in a neurotic way), without it being the case that this reason - which, under its causal description is efficient - is connected in the appropriate logical way to his or her other ideas, beliefs or desires. Psycho-analytic theory is on this view concerned especially, though not exclusively, with non-logical causal relations between quasi-autonomous parts of a divided mind.

Davidson's account thus seems to imply that Freudian theory is specifically applicable to the kind of behaviour that is to be characterized as irrational. Indeed, he interprets the theory of the unconscious simply as one among a number of rival theories of irrationality, which shows how mental states (reasons, desires, etc.), when they function as causes, can override rational judgement.

The discussion around this point - the relation between explanation in terms of cause and explanation in terms of reason, motive, intention, etc. - has become ever more sophisticated in recent English-language philosophy. James Hopkins observes in this connexion ${ }^{16}$ (here he roughly follows Wittgenstein) that the meaning of a word or sentence is partly to be understood via its use for the purpose of saying certain things, and hence the reason or reasons for which it is uttered. And citing a belief plus desire for acting in a certain way can serve to explain an action. A belief plus desire which can be used to explain the presence of another desire (again, to act in a certain way) will be similarly related to the second desire. We have already seen that Wittgenstein thought that psycho-analytic explanation must be of this « logical » or intentional kind. Alasdair MacIntyre, in his book The Unconscious, takes a similar line. What he calls Freud's simultaneous treatment of unconscious motives as both purpose and cause is, in his view, a pure confusion ${ }^{17}$.

A quarter of a century after MacIntyre's book, Anglophone philosophers have learned to take a more refined view. Thus Hopkins (see above) claims for example that desires and beliefs involve dispositions of a special and complex kind, including dispositions to generate further desires and beliefs. And underlying any disposition are the mechanisms by means of which its manifestations are produced. But these mechanisms are of the brain. They are therefore causal in type. So explanation by reason does bring information to bear which is ultimately causal, but by specifying patterns of causes operating in combination rather than by exhibiting causal sequences as instances of laws. This last point entails that we cannot test accounts of a person's reasons for acting by invoking such laws.

16. ID., « Introduction : Philosophy and Psychoanalysis », in R. Wollheim, J. HopKINS, eds, op. cit. supra n. 12.

17. Alasdair MAcINTYRE, The Unconscious, London, Routledge, 1958. 
What is at stake here is therefore, in this view, not the question whether psycho-analytic explanation is to be taken as modelled on that of the physical sciences. It is rather whether causal explanation of some type, perhaps different from that proper to the physical sciences, is made use of by psycho-analysis. Hopkins thinks that it is. Wish-fulfilment, for example, involves the imaginary representation of the gratification of the relevant wish. This can be effected by intentional activity ; in other words, intentional actions may be governed by such imaginative representation. But the fact that these actions are thus to be intentionally explained does not imply that the activity of the imagination is itself to be explained in the same way. We can think of imagining, says Hopkins, " as like breathing, which follows a natural course in adjustment to need unless intention or will intervene ").

One may be suspicious of such suggestions. But they do lie in a line pioneered by Freud himself. Freud believed that human behaviour must be explained by reference to both psychological and physical categories. Indeed, he used analogies from the natural sciences - in particular from biology - in his psychological theory. Thomas Nagel rightly points out ${ }^{18}$ that the question as to what sense it makes to think about a physical system in mentalistic terms bears not only on psycho-analytic theory but also on disputes about the status of mentalistic hypotheses in linguistics (cf. the discussion of Davidson, above). Noam Chomsky, for instance, has notoriously suggested that we can learn something about the brain by developing a mentalistic theory in linguistics ${ }^{19}$. According to this theory we can come to discover syntactic and semantic rules such that people talk " as if " they were following them. But leaving aside for a moment the general question of the status of such theoretical " discoveries ", it is in any case arguable, as Nagel observes, that if statable rules are not followed consciously, then it is unclear whether they can be said to be followed at all - that is to say, it is unclear that rules of language can be discovered (as the neo-Tarskian proponents of truth-functional semantics believe) such that it may be said that people follow them unconsciously. Such suppositions are one of the targets of Wittgenstein's Philosophical Investigations.

Are these suppositions not simply misconceived? Chomsky for instance goes so far as to posit " tacit knowledge " of the relevant calculus of meaning. He then describes « linguistic competence " (which he identifies

18. Cf. Thomas Nagel, "Freud's Anthropomorphism ", in R. Wollheim, J. Hopkins, eds, op. cit. supra n. 12.

19. Noam CHOMSKY, Aspects of the Theory of Syntax, Cambridge, Mass., M.I.T. Press, 1965. 
with the "language faculty ") as a causal mechanism determining linguistic performance. And this language faculty is itself characterized as constituted by a system of computational rules and representations ${ }^{20}$. Realizing, apparently, that this terminological usage is not without its difficulties, he introduces a new " technical » term : " Let us say ", he writes, « that if a speaker knows the language $L$, then he cognizes $L .$. He cognizes [even] those [principles and rules of his internalized grammar] that are forever hidden from consciousness " ${ }^{21}$. Chomsky thinks that the sense of the verb «to cognize " is very similar to that of the verb « to know " - except that (as Baker and Hacker point out) a person who thus cognizes something cannot tell anyone what he cognizes, cannot display the object of his cognizing, does not recognize the object of his cognizing when told what this object is, never learns what he cognizes, never forgets it but is incapable of teaching it, and so on. In other words, cognizing is " just like " knowing except for the fact that it is totally different from the latter in all relevant respects. Similar objections could be made against the notion of « tacit knowledge " made use of by many contemporary Anglophone philosophers, even if their positions are generally more subtle than those of Chomsky.

Now there is a certain parallel between the problems encountered by such theories of meaning on the one hand, and those posed by some of the same philosophers' exegesis and critique of psycho-analytic theory. This parallel lies in the fact that in both cases there is an attempt to explain linguistic and other behaviour in terms of a " deeper level » sphere which is supposed both causally to determine and to « guide " that behaviour. There are of course different versions of this combination of projects, some more obviously open to refutation than others. But we can generally say that, if we are to explain behaviour, including linguistic behaviour, by reference to the reasons, motives, desires and of course beliefs of the person in question, then the explanation must make reference to that person's own conceptual organization of experience, therefore to his own language - and that means to a set of syntactical and semantic rules available to him, and with which he is in some strong sense really acquainted. This leaves no room for « hidden rules ", which he follows without somewhere or somehow being aware of the fact.

There is, as we already mentioned, an old and powerful current in the history of philosophy which considers ordinary language to be radically defective, or alternatively to be misleading with respect to its

20. ID., Rules and Representations, Oxford, Blackwell, 1980.

21. ID., Reflections on Language, London, Fontana, 1976 ; quoted by G. P. BAKER, P. M. S. HACKER, op. cit. supra n. 11, p. 343. 
true logical form. Wittgenstein pillories this current in his later work. In the Philosophical Investigations he remarks for instance (in section 97) that

"we are under the illusion that what is peculiar, profound, essential, in our investigation, resides in its trying to grasp the incomparable essence of language. That is, the order existing between the concepts of proposition, word, proof, truth, experience and so on. This order is a super-order between - so to speak - super-concepts. "

But in fact, he continues, " every sentence in our language "is in order as it is". That is to say, we are not striving after an ideal " (section 98); and (108) : " The preconceived idea of crystalline purity ${ }^{22}$ can only be removed by turning our whole examination around. "

The calculus view of language dates, as we already noted, at least from Leibniz. In his work it was specifically linked with the notion of the desirability of the construction of a formal logic or calculus of discovery. Present-day Leibnizians would like to establish a new calculus ratiocinator, which would hold centre stage in the study of the structure of the human mind and of language.

It is perhaps a sign of Leibniz's continuing influence in contemporary, post-Wittgensteinian Anglophone philosophy that the calculus view of language remains so popular - or we might perhaps rather say that it is not surprising, in the light of recent developments in symbolic logic and computer science and of their exploitation in the ideologies of $\alpha$ information " and " communication ", that Leibniz should have retained his popularity. This is true, for instance, of fields such as the study of identity, sort and substance, and of the expanding domain of « possible worlds " ${ }^{23}$. But the essence of the neo-Leibnizian presupposition can be found in much other philosophical reflexion, including studies on psychoanalytic theory.

Here I shall mention only one example from English-language philosophy, namely the paper of Patrick Suppes and Hermine Warren entitled "On the Generation and Classification of Defence Mechanisms" ${ }^{24}$. This is intended as « an attempt to work out the rudimentary principles of a theory of the defence mechanisms ». This attempt « falls generally within the framework of the use of mathematical models in psychology ". In order to be able to apply their model, Suppes and Warren are obliged to clear the conceptual ground. This they do in their own cavalier way. For

22. This argument was aimed, among other targets, at his own earlier Tractatus view of an a priori order of the world and of thought.

23. See for example the work of David Wiggins, David Lewis, Arthur Smullyan, etc. This work is in part a " spin-off " from truth-functional semantics and the like.

24. Cf. R. Wollheim, J. Hopkins, eds, op. cit. supra n. 12, p. 163-179. 
instance, Freud (as they note) had spoken of the Unconscious as being composed of ideas. But Suppes and Warren are unable to define the notion of « idea " with sufficient precision, and so substitute for it that of proposition - apparently without realizing that this radically changes the terms of the question. It then « becomes natural to define the defence mechanisms as transformations of propositions $»$. Such a tranformation is characterized as « a function that maps unconscious propositions... into conscious propositions $»$. The authors believe that progress in psychoanalytic theory is to be made by the application of a " systematic formal approach ". By means of this approach they claim to have generated 44 elementary defence mechanisms, out of propositions of the form « actoraction-object " and three transformation-types (of the actor, action and object), and this by a purely formalist, logico-mathematical operation.

It is, for reasons already referred to, not surprising that contemporary Anglophone philosophers should attempt to apply a formal, semialgebraic method to a central question of psycho-analytic theory. What is perhaps more surprising is that the turn towards formalism, often considered typical of English-speaking philosophy, should have made such a deep impact in France. I shall do no more here than make brief reference to some key moments in this development. But I believe that the phenomenon deserves deeper study.

As early as 1966 Jacques-Alain Miller, in an article in the Cahiers pour l'analyse ${ }^{25}$, suggested shoring up the theory of Lacan with supports drawn from the work of Frege. Thus Miller introduces a definition of " identity " - and so, following Frege, of the concept of number which is " pivotal in Frege's system » and which the latter « draws from Leibniz ». Miller continues :

« Soit une chose $X$ du monde. Soit le concept empirique de cet $X$. Le concept qui prend place dans le schéma [de Frege] n'est pas ce concept empirique, mais celui qui le redouble, étant « identique au concept de $X$ ». L'objet qui tombe sous ce concept est $X$ lui-même $[. .$.$] Le nombre [. .$.$] à assigner$ au concept de X sera le nombre 1 [...] Le concept de la non-identite-d-soi est assigné par le numéro zéro qui suture le discours logique." "

So far, so good. We now arrive at the point of application to psychoanalytic theory. The relevance of the Fregean definition of the numbers is supposed to be that :

" Le rapport dit, dans l'algèbre lacanienne, du sujet au champ de l'Autre (comme lieu de la vérité) s'identifie à celui que le zéro entretient avec

25. Jacques-Alain MilLeR, « La Suture (Éléments de la logique du signifiant) », Cahiers pour l'Analyse (Paris, Seuil), 1, 1966, p. 37-49. 
l'identité de l'unique comme support de la vérité [...] La définition du sujet le réduit à la possibilité d'un signifiant de plus » 26 .

Thus the subject, being « non-identical-with-itself », cannot exist.

Now this « definition » is meant to yield a concept of the subject which avoids psychologism. Does this look reasonable ? Well, it is true that Frege was an opponent of psychologism. But the difficulty is that his aim was not at all to get rid of the " psychological subject " ; it was simply to insulate logic from psychology, the latter discipline being left untouched. One might of course argue that Frege's aim of insulation was misconceived, and that his logical doctrine can in fact quite well be applied, in a critical manner, to the field of psychology. But the historical incongruity would have to be cleared up.

What of the theory of numbers itself ? Does it constitute a firmly established achievement on which one can build ? Here too there is a difficulty. Frege, who was a mathematician rather than a philosopher, relies in this connexion on a rather controversial notion of the "laws of truth ", including the " law of identity ». Here too it is Wittgenstein who has asked the difficult questions. He notes for example that « Frege calls it "a law about what men take for true" that "it is impossible for human beings [...] to recognize an object as different from itself" ". But what kind of impossibility would this be ? It cannot (on Frege's own account) be a psychological impossibility ; in fact, says Wittgenstein, it is no more than grammatical ${ }^{27}$. But from the grammatical fact that, for instance, the same name is (other things being equal) taken to designate, in its various occurrences, one and the same thing, we cannot derive some so-called logical law asserting the necessary identity of a thing with itself. This is however what Frege relies on. He begins, it is true, with a metalinguistic account of identity statements. Thus the identity statement " $\mathbf{A}=\mathbf{B}$ » is taken to state that two names, " $\mathbf{A}$ " and " $\mathbf{B}$ », designate one and the same object. But this of course requires a non-trivial proof. Now Frege defines the concept of number by a specification of the conditions of identity of numbers. But - as Baker and Hacker point out ${ }^{28}$ - numerical identities in mathematics also typically require the support of non-trivial proofs. How then can Frege make use of the concept of identity in order to define numbers, which are themselves normally required in order to produce the above-mentionel non-trivial

26. Ibid., p. 43-44, 47-48.

27. See Remarks on the Foundation of Mathematics, Oxford, Blackwell, $3^{\text {rd }}$ ed. 1978, p. 89, 95. Cf. G. P. BAKer, P. M. S. HACKER, Frege : Logical Excavations, Oxford, Blackwell, 1984.

28. G. P. BAKER, P. M. S. HACKer, op. cit. supra n. 27, p. 221. 
proofs of given numerical identities ? He insisted that, for example, to assert that " the number of $F$ s is identical with the number of $G s$ " is to make an assertion about symbols (cf. supra). This makes sense, in the light of the above remarks, but does not explain how he can nevertheless found his definitions on a (more) primitive notion of identity. He seems to have attempted to resolve this problem by distinguishing between assertions like that just cited on the one hand, and sentences of the type " Fs are one-to-one correlated with $G$ s " on the other, which are not about symbols, but about self-subsistent or Platonic objects. The metalinguistic analysis is here abandoned, and for good reason : for in the case of an identity " $\vdash \mathrm{A}=\mathrm{B} »$, which is not about symbols but about objects (that is, where the " content " of " $A$ " is the object $A$, and the " content " of « B » the object B, and A and B are the same object), the identity needs no proof, but is an exemplification of the logical axiom " $\mathbf{A}=\mathbf{A}$ ». The problem arises ${ }^{29}$ when Frege goes on to infer identities of the former, metalinguistic kind from identities of the latter kind. Moreover, everything now rests on the logical axiom. But one might argue - as Wittgenstein does - that this so-called "law of identity " is a paradigm case of a useless proposition - rather like the proposition "Everything fits into its own shape ". It is in fact nonsense (and may be more easily seen as such by being compared with the obvious nonsense of the proposition " a thing is very similar to itself ").

These remarks are intended to suggest that Frege's definition of the concept of number and of number words is of controversial status, and that Wittgenstein's remarks on the " law of identity " help to draw attention to the difficulties which it involves. Frege's work has nevertheless been a source of inspiration for recent French and Anglophone thought. Indeed, Dummett claims that Frege was, in effect, the founder of analytic philosophy in general. What is in any case clear is that, like Tarski, Frege - in a particular interpretation of his work - has served as one of the influential sources for contemporary philosophy of language, and in particular for the theory of truth-conditional semantics. Thus two questions can be raised : first, how adequate are Frege's theories? And second, how faithfully are they interpreted by contemporary Anglophone philosophers ? For present purposes it is enough to note that neither of these questions is yet resolved; and that there are reasons to suppose that Frege has, in certain key respects, been quite wrongly interpreted in Britain and America ${ }^{30}$. For instance as a Platonist, Frege was

29. Ibid., p. 220-223.

30. Cf. ibid., p. 372 : « there is overwhelming evidence that in every major respect the whole modern conception of truth-conditional semantics is inconsistent with [Frege's] leading ideas. " 
opposed not only to psychologism but also to formalism. Yet his work is often interpreted in a formalist sense.

Let us now return to France. As we already noted, here too Frege has resurfaced to play a rôle in recent intellectual history, a rôle which has to do in particular with the search by Lacan for a philosophical foundation for his « return to Freud ». Elisabeth Roudinesco remarks that Lacan had, for some time, been on the look-out for a way of formalizing his doctrine. This search took the form, around 1969, of an intensive study of Wittgenstein's Tractatus. Whether or not he understood the sense of this work remains unclear. In any case he and his closest collaborators also sought inspiration in Leibniz and Frege, in an attempt to produce a universally true, scientific (because formalized) theory of the Unconscious.

In France, as in Britain and the USA, the renewed interest in these thinkers is linked to the development of the theory of language. Roudinesco has summed up the comparative situation in the mid-1960s :

" Au contraire des pays anglo-saxons où l'héritage frégéen domine la scène épistémologique, la France de cette époque est en retard sur le terrain de la logique. En 1965, les travaux de Frege et, de ses successeurs restent mal connus d'une intelligentsia marquée par une autre tradition en matière d'histoire des sciences. Cependant, avec l'explosion structuraliste se produit une interrogation neuve sur la logique dans la mesure où l'étude des structures linguistiques tend à déboucher sur l'appréhension des phénomènes généraux de la pensée et du langage " ${ }^{31}$.

In this situation, Lacan, influenced by his reading of Saussure and Jakobson, decided to intensify his study of linguistic and logical theory. Following Jakobson, he rejected Chomsky's approach. He then introduced a certain interpretation - yet another - of Frege, in order to legitimate his new formalist doctrine. He appears to have thought that the Wittgenstein of the Tractatus on the one hand and Frege on the other were simply complementary sources for carrying through this project, whereas in reality they are far apart ${ }^{32}$.

31. Elisabeth ROUDinesco, Histoire de la psychanalyse en France. 2 : 1925-1985, Paris, Seuil, 1986, p. 408.

32. Cf. G. P. BAKER, P. M. S. HACKer, op. cit. supra n. 27, p. 373-374 : "Wittgenstein criticized the conception of logical truth that he discerned to be common to Frege and Russell [...] Those philosophers who were converted to the modern semantic conception of validity were directly influenced in this matter by the Tractatus, not by Frege. " And p. 380 : " The whole conception of truth-conditions [...] commanded great interest when published by Wittgenstein. But it is far from any conception identifiable in Frege's work [...] The concept [of truth-conditions] [...] explained [in Wittgenstein's Tractatus] manifestly does not fit Frege's conception of sense ", and so on. 
In his seminar of 1969-1970, « L'Envers de la psychanalyse », the foundation was laid for this formalization of psycho-analytic theory. One of its aspects - presumably inspired by Leibniz and his mathesis universalis - is the search for the mathemes of psycho-analysis. This term refers to something like the set of algebraic equations or formulae permitting the formalization of psycho-analytic theory (and therefore its transmission outside of the analytic cure - for example in the university).

Lacan had always rejected the notion of the Cartesian ego. Now the matheme came to fill the void left by this rejection. It introduced - at least in principle - the possibility of the non-conflictual transmission of an established doctrine. Thus the spirit of Leibniz gradually came to dominate the Lacanian school. Armed at the front door against Cartesianism, Lacan allowed a version of logical formalism to walk through an open back door. The words of Françoise Gadet and Michel Pêcheux are relevant here. They argue that there is a sense of the phrase " the critique of language " in which it signifies an enterprise aimed at achieving a mastery over language, with the goal of purging it, of getting rid of its irrational attachments in order to reform it and transform it into a language in conformity with the principle of Reason. This tendency, they add, which is based on a logicist philosophy that renews the links with the Leibnizian attempt to found an ideal language called the Universal Characteristic, is in fact a version of neopositivism ${ }^{33}$. And Roudinesco has gone so far as to conclude that \& the logicism of the "mathemes" is the manner in which neo-positivism, dominant on the other side of the Atlantic, has infiltrated into France in the disccourse of the psycho-analyst ${ }^{34}$.

There does indeed seem to exist a parallel between the recent rise, in both the English-speaking and the French intellectual world, of neoLeibnizian and neo-Fregean theories of language. To the extent that these theories are open to criticism - for example of a Wittgensteinian kind so too is Lacan's recast doctrine. I shall attempt to outline, in a brief and simplified manner, why this doctrine is vulnerable.

Lacan redescribes various psychical processes identified by Freud : for example that of de-cathexis, free cathexis and re-cathexis, whereby a quantum of psychic energy is detached from a given idea, and re-attached to a new idea (a common example of such a process being that which results in the phobias). Now Lacan prefers to speak of a "metaphoric"

33. Françoise GADEt, Michel PECheux, La Langue introuvable, Paris, Maspero, 1981, p. 114 .

34. E. Roudinesco, Pour une politique de la psychanalyse, Paris, Maspero, 1977, p. 113. 
process which operates according to " the laws of language ". What happens, according to Lacan, is that one " signifier » is replaced by another " signifier ", the first being sent to the Unconscious. There it loses its original signifying function. It would as a consequence become just an " unverbalized image " - what Freud calls a " concrete idea " were it not for the fact that the Unconscious imposes a new structure on it. But how can this happen ? It happens because, in Lacan's words, " the Unconscious is [itself] structured like a language ". But it is not structured like our everyday or ordinary language. It has its own syntactical structure, which has no culturally specific history or character, but is universally present in all societies and persons.

Now everything that is psycho-analytically interesting about the behaviour of people will be explained in terms of this " language of the Unconscious " and its laws. But here the difficulties begin. For what kind of explanation will this be ? It must, it seems, be of a causal type ; for the " linguistic laws " of the Unconscious cannot, on the above account, be considered as rules of language, which a person follows (or fails to follow). He can neither apply nor violate them, since they are unknown to him, even though they determine his behaviour. Indeed, it is the fact that they are universal laws which no-one has to learn that makes it possible for Lacan to formulate them in the artificial, formalized language of the mathemes.

The formal language of the Unconscious does not, we have just argued, have rules; for if it had rules we should need to presuppose an agent which applied (or misapplied) them. It must therefore function according to causal laws. There must, broadly, be a causal mechanism at work, which it is the task of the theorist of psycho-analysis to discover.

What is striking about Lacan's approach is that he has invoked a conception of language comparable in certain key respects with the newly popular philosophies of language referred to above, which have come to dominate English-language philosophy. But these philosophies of language, popular as they may presently be, are not unassailable. They have indeed been heavily criticized ${ }^{35}$. One of the central points of this criticism is that it is nonsense to speak of languages which function according to laws or rules of which no-one is aware. One cannot follow rules which one does not understand. Nor can a scientist " discover " that someone has been unconsciously following a rule of which he has, up to that moment, been incognizant. Rules, so it is argued, are not explanatory hypotheses about behaviour. One cannot construct theories about rules in order to explain behaviour which is rule-governed. The

35. In particular by G. P. BAKER, P. M. S. HACKER, op. cit. supra n. 11. 
alternative is indeed to abandon the notion that the "language of the Unconscious » possesses any rules, and to suppose that it functions (as already suggested) according to a mechanism of causal laws. But in that case it can no longer be called a language. Or rather : we might, as Wittgenstein suggests, extend the concept of language to cover new kinds of things - as for example when we talk about a « computer language » or even about " the language of nature ». But these would not be core usages. They involve dropping a large part of the core sense of the concept of language, including that part of it which enables us to understand how languages work - namely by being learned, in a process of trial and error, and in being applied and misapplied and creatively extended by their practitioners.

What Lacan seems to want to do is just what this argument rules out. His concept of the Unconscious is of something which appears to function " like a language ", that is, through the application of rules, but which in fact operates as a causal mechanism. Such a mechanism is however, for reasons discussed above, unsuitable for the explanation of intentional or purposive behaviour, whether conscious or unconscious. At least, this must be the conclusion drawn by anyone who follows the general line of argument of the later Wittgenstein.

Let us therefore, in closing, return to this Wittgenstein, the author of the Philosophical Investigations. There, as we noted, one of his principal aims was to oppose the calculus view of language. He tried not only to show the faults in this view, but also to account for its popularity. As Brian McGuinness points out, in a commentary on Wittgenstein, people have for example the feeling that, by giving a name to something, they come to master it. They obtain an " angel's knowledge », and this pleases them. But we must resist the charms of this fool's paradise. We must break free of the bewitchment by language induced by the mythological picture implicit in our first reflexions on it.

" This (it seems to me) », writes McGuinness, « is what made it natural for [Wittgenstein] to call himself a pupil or follower of Freud, for he had in Freud an example of how a new and deeper but often less flattering interpretation could be substituted for the apparent meaning and at the same time of how a mythology could captivate $"{ }^{36}$.

36. Cf. "Freud and Wittgenstein », in B. MoGuinness, ed., op. cit. supra n. 6, p. 42-43. See also Jacques Bouveresse, "Wittgenstein face à la psychanalyse ", Austriaca (Univ. de Haute-Normandie), 21, nov. 1985, for a useful discussion of this and other questions raised in the present paper. 
Wittgenstein is the « disciple » of Freud who seems to do nothing but raise objections to his master. Lacan is the " disciple " of Freud who means to impose a return to Freudian orthodoxy. The question however remains open as to which of these two thinkers may be said to be closest to the spirit of Freud's work. What we might say, in any case, is that with respect to the Lacan of the 1970s at least, Wittgenstein (who died in 1951) may be called an anti-Lacan avant la lettre ${ }^{37}$.

Grahame Lock, Catholic University of Nijmegen.

37. This article is based in part on lectures and seminars held at Oxford University, in the Sub-faculty of Philosophy, and at the College international de philosophie in Paris, which institutions I thank for their hospitality. 